\title{
KARAKTERISTIK DAN POLA PERGERAKAN PENDUDUK KOTA BATAM DAN HUBUNGANNYA DENGAN PERKEMBANGAN WILAYAH HINTERLAND
}

\author{
Imam setiyohadi
}

\author{
Dosen Jurusan Teknik Sipil Fakultas Teknik Universitas Riau Kepulauan
}

\begin{abstract}
ABSTRAK
Batam Island's role as an industrial development center causes fast-paced growth in many sectors with an uneven inhabitant distribution. With most people inhabit the Batam city.The hinterland area is characterised by islands and housing pattern of community clusters in the form of fishermen's neighborhood along the coastal region with most of the houses are semi-permanent buildings. Most of people's activities there are consisted of fishing. With limited infrastructure, the mode of transportation used in between the many islands there is with motor boats (Pancung). This is very much in contrast with the condition down the Batam City, in terms of its socio-economic, housing and other aspects. This research is aimed at figuring out the reason as to why people prefer to have their house located in rural areas and finding out the characteristic pattern of people's movement around the Batam Island.
\end{abstract}

Samples were taken using the sample random proporsional method. Samples were taken randomly from many districts with a proper ratio of people from weak, middle and upper class economic strata. The data were then analyized with cross classification.Results show that people chose rural areas because that where the industrial locations are so that it is closer for them to go to work, and the housin price or rent there are relatively cheaper too. Whereas people who chose to live in the Batam City do so because they want to improve their livelyhood by opening up alternative businesses other than working within the industry.

People's traveling destination is in and around the rural areas because it is where the industries are located evenly and the rest of them travel to the areas surrounding Batam Island. Such as people of Nongsa, 23\% of the travel to the Kabil industrial area, and $12 \%$ of them go to the city center (Nagoya). In contrast, people of the Sekupang District, 29\% of them travel only in and around Sekupang area. Other than that only $2 \%$ of Batam inhabitants travel to the islands surrounding Batam Island. Whereas for the people of Sei Beduk, 29\% of them go to Muka Kuning and $14 \%$ of them to the city center. And for the people of Lubuk Baja District, $32 \%$ of them go to the city center (Nagoya), because it is actually the CBD center.The type of transportation used by people in rural areas are mostly private vehicles because they are thought to be more comfortable and safe, as is the case for Nongsa and Sekupang. Nonetheless, $2 \%$ of Sekupang inhabitants use motor boats to travel to the islands surrounding Batam Island. In Nongsa, $36 \%$ of the people use motorcycle, public transportation account for $32 \%$, and in Sekupang car owners are around 35\%. Contrary, the people of Sei Beduk are mostly using public transportation, $42 \%$, due to the already availabel public road and vehicles and only $34 \%$ use cars. As for the distance covered by those people, Nongsa and Sekupang residents are $42 \%$ cover around 5-10 Km with a travel time of 20-30 minutes a day. Whereas the people of Sei Beduk, $45 \%$ of them only cover $105 \mathrm{~km}$ in around 10 minutes a day due to the proximity of their living place with the industrial location.

On the other hand, Lubuk Baja (city center) people are $43 \%$ using cars, for the are much more comfortable and allow them to have higher mobility. And only $31 \%$ of the 
inhabitants there use public transportation. Most of the people there cover 1-5 km (52\%) to 5$10 \mathrm{~km}(27 \%)$ a day with a travel time of around 10 to 20-30 minutes.

Keywords: Sample, Hinterland Area, Travelling Characteristic

\section{PENDAHULUAN}

\section{Latar Belakang}

Kota Batam adalah salah satu kota yang berada di Propinsi Kepulauan Riau, dan terletak di wilayah pengembangan segitiga Singapura - Johor - Riau ( SIJORI ) yang merupakan kawasan yang secara khusus dikembangkan untuk industri, alih kapal, dan pariwisata.

Strategi dan kebijakan dalam pengembangan daerah hinterland secara umum adalah pembangunan dan penyediaan infrastruktur dasar yang dapat mendorong tumbuhnya kegiatan ekonomi yang kelak akan membawa kesejahteraan bagi penduduknya.Di daerah hinterland yang mempunyai karakteristik kepulauan, pola permukiman pada umumnya bersifat desa/kelurahan berupa perkampungan nelayan tradisional dengan aktifitas ekonomi penduduk banyak dilakukan di luar wilayah desa seperti penangkapan ikan di laut, bekerja di kota dan sebagainya. Dengan demikian pendekatan pengembangan infrastruktur daerah hinterland Kota Batam berbasiskan Pengembangan infrastruktur kawasan

Dalam Pengembangan kawasan khususnya permukiman di daerah hinterland, diperlukan suatu justifikasi dimana persoalan jalan, transportasi pengangkutan menjadi kendala klasik. Ini menjadi dasar utama dalam menciptakan interaksi perkembangan kawasan perkotaan dan kawasan hinterland.

Dampak lain dari pertumbuhan Pulau Batam adalah adanya arus migrasi dan tumbuhnya rumah-rumah liar (ruli). Ruli-ruli tersebut tumbuh terutama akibat kemampuan ekonomi finansial dari sebagian migran yang rendah sehingga menyebabkan mereka tidak memiliki kemampuan cukup untuk mendapatkan fasilitas bermukim secara formal.ruli yang cenderung 
tumbuh meluas pada skala lingkungan telah banyak menempati kawasan-kawasan yang semestinya berfungsi lindung.

Bila dibandingkan dengan wilayah di kepulauan perkembangan jumlah penduduk di kecamatan Pulau Batam jauh lebih tinggi terutama di kecamatan pusat pengembangan kegiatan perkotaan. kondisi ini muncul karena perkembangan kegiatan budaya perkotaan diwilayah Pulau Batam yang menyerap lapangan pekerjaan dan sehingga memiliki daya tarik penduduk untuk tinggal di pulau Batam. Sedangkan kondisi di wilayah kepulauan ( Kecamatan Belakang Padang, Kecamatan Galang, Kecamatan Bulang ) masih didominasi kegiatan non budaya dan budaya pedesaan.

Untuk mendapatkan tempat tinggal di pusat kota saat ini sangatlah sulit tentu karena faktor harga yang relatif mahal, maka bagi penduduk golongan menengah ke bawah solusinya adalah mencari tempat tinggal di daerah pinggiran kota.

Kecenderungan yang terjadi di kota Batam adalah adanya pola perjalanan yang memusat khususnya perjalanan dari rumah menuju daerah perkantoran, pabrik tempat kerja, dan pusat pelayanan jasa. Hal ini disebabkan perkembangan yang sangat pesat pada pusat kegiatan komersil di tengah kota. Sementara pada kawasan-kawasan permukiman baru yang berkembang di daerah baru kurang mendapatkan pelayanan yang memadai.

Bahwa lebih dari $90 \%$ perjalanan berbasis tempat tinggal artinya mereka memulai perjalanan dari tempat tinggal (rumah) dan mengakhiri perjalanan kembali kerumah. Oleh karena itu pergerakan antara tempat tinggal dengan tempat kerja/sekolah akan menambah karakteristik pola pergerakan penduduk. Semakin jauh tempat tinggal dengan tempat aktifitas sehari-hari maka akan semakin menambah beban lalu lintas di jalan akibat adanya akumulasi lalu lintas yang menuju ke pusat kota. Hal ini menyebabkan gangguan pelayanan transportasi antara lain dengan timbulnya kemacetan di beberapa ruas jalan.

\section{Rumusan Masalah}

Sejalan dengan pelaksanaan pembangunan fasilitas dan infrastruktur pendukung di Kota Batam seperti prasarana jalan raya sepanjang 807,26 Km, jembatan Barelang sepanjang $2.262 \mathrm{~m}$ yang menghubungkan 7 buah pulau dan lain-lainnya, maka perkembangan guna lahan pada beberapa kawasan di Kota Batam telah berkembang menjadi kawasan - kawasan yang produktif, seperti kawasan industri, kawasan wisata, kawasan perdagangan, dan kawasan permukiman. Kondisi ini akan memacu terjadinya peningkatan kebutuhan perumahan atau tempat tinggal serta transportasi untuk mendukung pergerakan antar kawasan tersebut. 
Masyarakat Batam yang rata-rata berasal dari luar Kota Batam atau kaum pendatang mereka berasal dari berbagai ragam suku/etnis,serta budaya yang berbeda, yang sekarang menjadi penduduk Kota Batam karakteristiknya sangat beragam hal ini tampak dalam ciri perumahannya maupun strata sosial, seperti kampung Aceh, kampung Jawa, kampung Bugis, kampung Melayu, kampung Cina dan lain-lain. Dengan adanya perbedaan suku/etnis tersebut mereka saling menghormati tidak mempermasahkan status asalnya, mereka sudah menjadi satu kesatuan masyarakat Kota Batam sebagai masyarakat yang sopan santun, disiplin, beradap serta berbudaya tinggi. Seiring dengan perkembangan Kota Batam kehidupan mereka sudah membaur.

Permasalahannya adalah bahwa perkembangan kota Batam yang demikian pesat secara umum orang ingin mendapatkan tempat tinggal yang dekat dengan tempat aktifitas sehari- hari, Tetapi dengan kondisi sekarang dimana tempat tinggal di pusat kota semakin sulit dan mahal sehingga tidak terjangkau bagi kalangan tertentu. Maka sehingga orang mencari alternatif tempat tinggal di daerah pinggiran kota/sub wilayah pengembangan dengan harapan bisa mendapatkan tempat tinggal dengan harga yang relatif lebih murah. Dan bagi mereka yang baru bertempat tinggal di Kota Batam ataupun pasangan-pasangan muda yang belum bekerja (golongan bridgeheaders) adalah golongan dengan segala keterbatasannya belum mampu mengangkat dirinya ke jenjang sosial ekonomi yang lebih tinggi. Kemampuan ekonominya belum meningkatkan untuk memiliki rumah sendiri.Berdasarkan hal tersebut ketika pemikiran diarah ke masa yang akan datang akan terlihat banyaknya problem yang akan dihadapi seiring dengan perubahan dan perkembangan yang terjadi mengingat kawasan sub wilayah pengembangan, dan hinterland kota batam akan berkembang pesat menjadi kawasan yang padat penduduknya, sedang pada sisi lain prasarana jalan perkembangannya sangat kecil yang menyebabkan kinerja jalan cepat mengalami penurunan. Banyak faktor-faktor terkait yang saling mempengaruhi, faktor-faktor tersebut diduga berhubungan dengan dengan perkembangan wilayah yang ditunjukan dengan perubahan tata guna lahan, perkembangan volume lalu lintas. Faktor yang tidak kalah penting adalah adanya pola pergerakan komuter penduduk yaitu berupa pergerakan pulang pergi yaitu penduduk yang pergi ketempat kerja dan kembali kerumah atau dari rumah menuju ke sekolah.

Oleh karena itu penting usaha-usaha perencanaan transportasi yang matang yang harus dilakukan sedini mungkin.

\section{Tujuan dan Manfaat Penelitian}

\section{Tujuan}

Tujuan dari penelitian ini yang ingin dicapai adalah :

1. Mengetahui alasan utama pemilihan hunian di daerah Hinterland /pinggiran kota dan pemilihan hunian di pusat kota.

2.Mengidentifikasi karakteristik pola perjalanan transportasi penduduk daerah Hinterland/pinggiran kota ( terkait dengan sebaran pergerakan, jarak, waktu tempuh, moda yang digunakan, maksud perjalanan dan biaya transportasi) yang akan dibandingkan dengan karakteristik perjalanan transportasi penduduk yang tinggal di pusat kota.

\section{Manfaat penelitian}

Adapun manfaat yang dapat diambil dalam penelitian ini adalah 
1. Dapat menjadi bahan pertimbangan untuk pengembangan sarana dan prasarana angkutan umum yang menghubungkan daerah hinterland/ pingiran kota dengan kota Batam.

2. Dapat mengetahui pergerakan penduduk yang terjadi apakah lebih banyak terjadi pergerakan lokal atau cenderung pergerakan ke pusat wilayah kegiatan perkotan mengingat perumahan yang dikarenakan jauh dari pusat kota yang menyebabkan biaya transportasi mahal yang berdampak pada mobilitas yang menurun.

3. Dapat menjadi bahan pertimbangan untuk perencanaan suatu kawasan dimasa yang akan datang.

\section{Batasan Masalah}

Dengan mempertimbangkan luasnya kajian yang diambil dalam penelitian ini, dan karena keterbatasan pada pelaksanaan penelitian serta luasnya wilayah kota Batam terdiri dari wilayah Pulau Batam sendiri dan wilayah kepulauan-kepulauan yang letaknya menyebar, maka digunakan batasanbatasan sebagai berikut:

1. Penelitian hanya dilakukan di Pulau Batam yaitu di Kecamatan Sei Beduk, Kecamatan Nongsa, Kecamatan Sekupang, Untuk mengambil sampel data penduduk pingiran kota Batam. Sedangkan sample data penduduk di pusat kota diambil di Kecamatan Lubuk Baja.

2. Metode yang digunakan untuk pengambilan sample adalah sample random proporsional yaitu pengambilan sample yang dilakukan secara acak pada lokasi Kecamatan yang diamati dengan memperhatikan golongan ekonomi lemah, golongan ekonomi sedang, golongan ekonomi kuat.

3. Karakteristik pola pergerjalanan yaitu sebaran pergerakan, jarak, jenis perjalanan, waktu tempuh, moda yang digunakan dan biaya transportasi.

\section{TINJAUAN PUSTAKA}

\section{Karakteristik Pola Pergerakan}

Keterkaitan antar wilayah ruang sangat berperan dalam menciptakan perjalanan. Menurut Tamin (1997) pola pergerakan di bagi dua yaitu pergerakan tidak spasial dan pergerakan spasial. Konsep mengenai pergerakan tidak spasial (tanpa batas ruang) didalam kota, misalnya mengenai mengapa orang melakukan perjalanan,kapan orang melakukan perjalanan, dan jenis angkutan apa yang digunakan.

Sedangkan konsep mengenai ciri pergerakan spasial (dengan batas ruang) di dalam kota berkaitan dengan distribusi spasial tata guna lahan yang terdapat di dalam suatu wilayah. Dalam hal ini, konsep dasarnya adalah bahwa suatu perjalanan dilakukan untuk melakukan kegiatan tertentu di lokasi yang dituju, dan lokasi terrsebut ditentukan oleh tata 
guna lahan kota tersebut. Pergerakan spasial dibedakan menjadi pola perjalanan orang dan perjalanan barang.

\section{Tata Guna Lahan dan Transportasi}

Tata guna lahan suatu kota pada hakekatnya berhubungan erat dengan system pergerakan yang ada. Perbaikan akses transportasi akan meningkatkan tarikan kegiatan dan berkembangnya guna lahan kota. Terjadinya pergerakan manusia dan barang di dalam kota, atau dapat disebut aruslalu lintas, merupakan konsekuensi akibat aktifitas tuntutan lahan dan kapabilitas sistem transportasi untuk mengakomodasi arus lalu lintas. Secara alamiah ada interaksi langsung antara jenis dan interaksi tata guna lahan dan pasokan prasarana transportasi.

\section{Faktor yang mempengaruhi}

Menurut Ofyar Z Tamin faktor-faktor yang diperhitungkan sebagai peubah penentu bangkitan pergerakan dari lingkungan perumahan adalah: Pendapatan, Pemilikan kendaraan, Struktur rumah tangga,nilai lahan, kepadatan daerah pemukiman,aksesibilitas Empat faktor pertama ( pendapatan, pemilikan kendaraan,struktur,dan ukuran rumah tangga) telah digunakan pada beberapa kajian bangkitan pergerakan, sedangkan nilai lahan dan kepadatan daerah pemukiman hanya sering dipakai untuk kajian mengenai zona.

\section{Pengujian statistik}

\section{Analisis Kategori atau Klasifikasi Silang}

Metode ini didasarkan pada adanya keterkaitan antara terjadinya pergerakan dengan atribut rumah tangga. Asumsi dasarnya adalah tingkat bangkitan pergerakan dapat dikatakan stabil dalam waktu untuk setiap stratifikasi rumah tangga tertentu. Metode analisa kategori sering digunakan untuk mendapatkan bangkitan lalu lintas untuk daerah permukiman tetapi dapat juga di pakai untuk aplikasi lainnya. Variabel yang biasa digunakan untuk analisis kategori adalah ukuran keluarga ( jumlah orang), pemilikan kendaraan, dan pendapatan keluarga.

\section{Penelitian sejenis}

Tingkat penggunaan kendaraan bermotor di Pulau Batam pada umumnya kendaraan bermotor atau motorized trip. Dan sebagian kecil non motorized trip $(12,97 \%)$. Dari sejumlah pengguna kenadaraan motorized trip yang berjumlah $87,03 \%$ pemisahan pengguna moda transport atau modal split antara pengguna kendaran pribadi dan angkutan umum menunjukan prosentase $85: 15$. 
Tingkat pengguna sarana angkutan sebesar $15 \%$. Hal ini menunjukkan tingkat pengguna sangat rendah. Jika dilihat dari pengguna angkutan taxi diperoleh angka 35,92\% yang menunjukkan angka cukup tinggi dan pengertian taxi di Pulau Batam adalah pengguna taxi kolektif . Bukan seperti halnya seperti private taxi dan angka ini mencapai $68,87 \%$ dari populasi pengguna non- private car.Yang termasuk didalamnya pengguna taxi tidak resmi.

Pertumbuhan mobil penumpang yang sebagian besar adalah kepemilikan kendaraan pribadi menunjukkan angka pertumbuhan $10 \%-15 \%$ sementara itu pertumbuhan angka bus hanya $7 \%-12 \%$. Terlebih lagi jika dilihat dari angka pertumbuhan angkutan umum bus yang relatif lambat. Kondisi lain akan mempercepat menurunnnya tingkat pelayanan jaringan jalan yang ada.

Bahwa perkembangan jumlah kendaraan untuk wilayah Pulau Batam berkisar $11 \%-18$ $\%$, dimana angkutan jenis truk memiliki angka pertumbuhan paling tinggi mencapai $11 \%$ pertahun, meskipun peningkatan bus untuk angkutan umum masih relatif rendah jika dibandingkan peningkatan kendaraan pribadi yang mencapai 14\% pertahun.

\section{METODOLOGI PENELITIAN}

\section{Uraian Umum}

Suatu penelitian membutuhkan pendekatan metodologi, secara harfiah metodologi adalah suatu pola pemikiran dalam menyusun sebuah studi. Tujuan yang ingin dicapai adalah untuk mengarahkan proses dalam penalaran, bagi hasil yang nantinya akan dicapai.

\section{Survei Pendahuluan}

Survei pendahuluan dilakukan sebelum penelitian sebenarnya dilakukan dengan tujuan untuk mengetahui kondisi dan karakteristik lokasi penelitian serta untuk dapat memperkirakan waktu dan biaya. Melalaui survei pendahuluan akan diperoleh data sekunder.

\section{Menentukan Ukuran Sampel}

Menurut Sugiyono (2005) secara matematis besarnya sampel dari suatu populasi dapat dirumuskan sebagai berikut;

$$
\mathrm{n} \geq\left(\frac{\sigma . z}{\mathrm{~b}}\right)^{2}
$$

Keterangan

$\mathrm{n} \quad=$ ukuran sampel yang diperlukan

$\mathrm{b}$ = perbedaan antara yang ditaksir dengan tolak ukur penaksiran 
$\mathrm{z}$ = harganya tergantung pada tarf kepercayaan yang ditetapkan missal pada taraf kepercayaan 95\% maka nilai $\mathrm{z}=1,96$; taraf kepercayaan 99\% maka nilai $\mathrm{z}=2,58$

$\sigma \quad$ = simpangan baku

\section{Output}

Dari hasil penelitian ini dapat diketahui karakteristik perjalanan penduduk di daerah pinggiran kota/hinterland kota Batam,( Kecamatan Sei Beduk, Kecamatan Nongsa, Kecamatan Sekupang) dan karakteristik perjalanan penduduk yang tinggal di pusat kota (Kecamatan Lubuk Baja), berupa sebaran pergerakan, jarak, dan lama perjalanan, dan moda yang digunakan berdasarkan jenis pekerjaan dan jumlah pendapatan. Kemudian dari hasil tersebut akan diberikan rekomendasi, alternatif pengembangan transportasi yang paling sesuai guna mengantisipasi kebutuhan akan transportasi dimasa mendatang yang semakin berkembang. Hasil penelitian ini juga dapat digunakan oleh pemerintah sebagai pengambil kebijakan untuk mendukung strategi perencanaan transportasi di kota Batam.

\section{PENGUMPULAN DATA DAN PEMBAHASAN}

\section{Pengumpulan Data}

Sesuai dengan batasan studi dalam penelitian ini .bahwa wilayah studi berada di pulau Batam, yaitu penduduk yang berada di hinterland /pinggiran Kota Batam (Pulau Batam). yaitu di Kecamatan Nongsa, Kecamatan Sekupang, Kecamatan Sei Beduk, sebagai wilayah pinggiran kota dan sebagai daerah pusat kota di Kecamatan Lubuk Baja. Pada penelitian ini data untuk kepentingan analisa adalah berupa data primer dan data sekunder.Data primer dalam penelitian ini didapat dengan cara menyebar daftar pertanyaan /kuesioner kepada responden di 4 (empat) kecamatan yaitu: Kecamatan Nongsa, Kecamatan Sekupang, Kecamatan Sei Beduk, Kecamatan Lubuk Baja.Responden yang diambil tidak semua populasi yang ada tetapi menggunakan sampel yang proporsional sehingga tetap mencerminkan kondisi yang sebenarnya.

Untuk mendapatkan /menentukan jumlah sampel yang akan diambil, dilakukan survai pendahuluan, sampel diambil secara acak dari n sampel yang berada di 4 kecamatan yang dimaksud dengan memperhatikan golongan I (ekonomi menengah bawah) golongan II (ekonomi menengah ) golongan III (ekonomi menengah atas). Hasil tersebut direkap dan di jumlah setiap variabel (pertanyaannya) kemudian di hitung $\mathrm{n}$ sampling untuk survai memwakili 4 kecamatan tersebut. Pada penelitian ini perbedaan hasil penaksiran dengan 
tolok ukur penafsiran adalah $10 \%$ atau 0,1 , dan $\mathrm{Z}$ score dengan taraf kepercayaan $95 \%=$ 1,96 9tabel Z score), simpangan baku 1,02. Dari perhitungan sampel didapatkan jumlah sampel 399 responden. Dari proporsi golongan yang diperoleh hasil sampling random, maka didapatkan Gol I ada 24 , golongan II ada 8 , dan golongan III ada 5.

$\mathrm{n} \geq(1.02 .1,96)^{2} / 0.1=399 \approx 400$ responden

jumlah sampel per golongan Misal Golongan III $=(5 / 37) \times 400=54$ begitu seterusnya untuk setiap golongan lainnya.Dari 400 responden tersebut dibagi dalam jumlah yang sama di setiap kecamatan, masing-masing tiap kecamatan ada 100 responden.Sedang untuk data sekunder berupa data gambaran umum wilayah penelitian, berbagai kebijakan pemerintah, studi-studi yang ada dan data-data lain yang berhubungan dengan penelitian dari Bappeko Kota Batam,Otorita Batam, dan berbagai instansi yang terkait. Data sekunder berguna sebagai pelengkap untuk analisa.

\section{Karakteristik Wilayah Studi}

\section{A. Kecamatan Nongsa}

Kedudukan Kecamatan Nongsa terhadap kota Batam adalah strategis, hal ini dilihat dari beberapa hal :

a. Fungsi sebagai wilayah untuk pengembangan industri berat, daerah pariwisata dan permukiman adanya fungsi ini membawa konsekwensi bahwa arus penduduk yang mengalir ke kawasan ini akan membutuhkan sarana dan prasarana pendukung yang akan berdampak pada percepatan perkembangan kawasan di Nongsa.

b. Secara geografis Wilayah Nongsa merupakan pintu masuk Kota Batam dari bagian Timur Laut dapat dikatakan merupakan pintu gerbang utama bagi Kota Batam.

c. Kecamatan Nongsa mempunyai wilayah yang cukup besar dibandingkan dengan luas kecamatan lainnya yang ada di Pulau Batam. Pada tahun-tahun terakhir ini sarat dengan kegiatan pembangunan kegiatan perkotaan yang menarik penduduk untuk tinggal di kecamatan ini, seperti kegiatan industri,pariwisata, perdagangan, dan jasa serta pembangunan perumahan sekala besar yang dikembangkan oleh pihak swasta. Kondisi ini menyebabkan wilayah Kecamatan Nongsa yang juga merupakan pusat pemerintahan Kota Batam banyak diminati penduduk untuk tinggal di Kecamatan Nongsa.

Adanya kawasan-kawasan permukiman baru itu yang memiliki akses langsung menuju jalan utama, sehingga menimbulkan keluhan dari pihak transportasi kota Batam, bahwa akan menimbulkan kemacetan dan kekacauan lalu lintas di jalan utama.

\section{B. Kecamatan Sekupang}


Laju pertumbuhan penduduk Kecamatan Sekupang pada tahun 2005 sebesar 0,61\%. Dengan kepadatan penduduk setiap $\mathrm{km}^{2} 1287$ jiwa dan rata- rata penduduk per rumah tangga 3 jiwa/KK.

Berdasarkan kebijakan yang ada dalam RTRW Kota Batam, Kecamatan Sekupang adalah kedudukannya sangat strategis, seperti pusat pelayanan industri. Lokasi yang sangat strategis adanya pelabuhan laut sebagai salah satu pintu gerbang masuk ke Pulau Batam dari Utara .Mengingat wilayah Sekupang selain untuk kegiatan industri,di bidang lain seperti jasa, pariwisata, dan perdagangan, serta permukiman membuat daya tarik penduduk untuk tinggal di wilayah ini.dengan adanya dukungan industri ini, hal ini menarik pihak swasta seperti pengembang perumahan banyak yang membangun kawasan perumahan untuk memenuhi kebutuhan akan rumah tinggal. Kawasan pengembangan sekupang merupakan kepadatan yang cukup tinggi.

\section{Kecamatan Sei Beduk}

Kedudukan Kecamatan Sei Beduk terhadap kota Batam adalah strategis, hal ini dilihat dari beberapa hal :

a. Sebagian besar kegiatan yang dikembangkan di kecamatan ini untuk kegiatan industri ,perdagangan dan jasa serta perumahan yang banyak menarik para migran pencari kerja untuk tinggal di kecamatan ini.A adanya fungsi ini membawa konsekwensi bahwa arus penduduk yang mengalir ke kawasan ini akan membutuhkan sarana dan prasarana pendukung yang akan berdampak pada percepatan perkembangan di wilayah Sei Beduk.

b. Banyaknya para pengembang perumahan/ property, yang membangun perumahan di kawasan ini,tersebar di seluruh wilayah Sei Beduk, hal ini disebabkan banyaknya kegiatan industri di wilayah ini.

\section{Kecamatan Lubuk Baja}

Kecamatan Lubuk Baja mempunyai letak yang sangat strategis sebagai pusat perdagangan dan bisnis di Kota Batam, bisa dianggap sebagai urat nadi pembangunan kota Batam karena hampir seluruh aktivitas ekonomi berpusat di daerah ini.

Tingkat pertumbuhan di kecamatan ini mengalami kejenuhan, selain itu ketersediaan lahan di kecamatan ini luas wilayahnya cukup kecil, sangat terbatas, dan sebagian besar peruntukan lahannya di prioritaskan untuk kegiatan komersil. Kondisi ini menyebabkan nilai dan harga lahan di Kecamatan ini relatif tinggi dibandingkan dengan wilayah lainnya. 


\section{ANALISA DAN PEMBAHASAN}

\section{Karakteristik Pola Perjalanan Penduduk Wilayah Pinggiran (Kecamatan Nongsa, Kecamatan Sekupang dan Kecamatan Sei Beduk)}

Maksud perjalanan sehari-hari/utama bagi penduduk di Kecamatan Nongsa adalah sebagian besar untuk bekerja yaitu sebesar $57 \%$ dan selebihnya untuk tujuan perjalanan yang lain seperti sekolah sebanyak $29 \%$, berbelanja dan kegiatan sosial masing-masing sebesar $8 \%$ dan $6 \%$.Jarak yang ditempuh penduduk untuk melakukan aktifitas sehari-hari ke tempat tujuan masing-masing dengan jarak tempuh antara $5-10 \mathrm{~km}$ sebesar $42 \%$. Dan penduduk yang menempuh jarak lebih besar dari $10 \mathrm{~km}$ untuk menuju ke tempat tujuan aktifitas sehari-hari yaitu sebanyak $15 \%$. Selain itu yang menempuh jarak 1-5 km juga cukup banyak yaitu sebesar $39 \%$. Dimana lokasi bekerja/sekolah sebagian masih berada di Nongsa sendiri tepatnya di daerah Industri Kabil dan Batu Besar, dan yang lain tersebar di luar Kecamatan Nongsa.Besarnya prosentase jarak perjalanan 1-5 km dilatar belakangi oleh status pekerjaan responden dimana lokasi bekerja dengan tempat tinggal relatif dekat yang akhirnya memperpendek jarak perjalanan yang harus di tempuh untuk mencapai tempat aktifitas. Waktu yang di tempuh untuk melakukan perjalanan menuju tempat tujuan seharihari dengan lama waktu perjalanan antara 20 -30 menit ( $32 \%$ ) sampai 30 - 40 menit ( $37 \%$ ). Lama perjalanan untuk menuju ke tempat kerja atau sekolah maupun ke tempat tujuan lain sangat di pengaruhi oleh jarak yang di tempuh dan moda yang digunakan

Dalam melakukan perjalanan sehari-hari sebanyak $36 \%$ menggunakan kendaraan sepeda motor dan sebanyak $32 \%$ menggunakan angkutan umum.dan penduduk dengan tingkat ekonomi yang lebih tinggi sebanyak $30 \%$ dalam melakukan perjalanan menggunakan mobil pribadi dengan alasan bahwa karena lebih merasa nyaman,aman dan dinilai lebih hemat .banyaknya aktifitas perjalanan menggunakan kendaraan pribadi ini lebih disebabkan karena status sosial ekonomi penduduk dan pengaruh budaya dan teknologi.Untuk keperluan biaya transportasi dari penduduk di Kecamatan Nongsa rata-rata mengeluarkan biaya antara Rp.200.000 - Rp.500.000 atau sebesar 39 \%. Dan lebih kecil atau sama dengan Rp. 200.000 sebanyak $54 \%$ kebanyakan mereka yang menggunakan angkutan umum, dengan demikian dapat dikatakan bahwa biaya yang dikeluarkan untuk transportasi hal ini juga sangat tergantung dari jarak yang ditempuh perjalanan dan moda yang digunakan.Kecenderungan dari penduduk pinggiran yaitu memilih daerah pinggiran dengan mempertimbangkan faktor 
aksesibilitas, karena itu mereka memilih daerah pinggiran yang sudah tertata yang memperhatikan aksesibilitas atau kemudahan dalam melakukan perjalanan, untuk aksesibilitas penduduk pinggiran lebih memilih menggunakan kendaraan pribadi karena kendaraan pribadi mempunyai aksesibilitas tinggi dan dinilai lebih aman, nyaman dan bebas dan tepat waktu.

Demikian halnya bagi penduduk di Wilayah Sekupang sebesar $66 \%$ maksud perjalanan sehari-hari / utama adalah sebagian besar adalah bekerja,. Selain bekerja tujuan perjalanan yang lain seperti untuk sekolah sebanyak $21 \%$, dan selebihnya untuk tujuan belanja dan kegiatan sosial lainnya.Dilihat dari jarak Jarak perjalanan yang ditempuh dari rumah ke tempat tujuan sehari-hari sebagian besar penduduk di Sekupang menempuh jarak antara 1 - $5 \mathrm{~km}$ hingga 5-10 km dengan waktu perjalanan 20 -30 menit hingga 30- 40 menit, Dimana lokasi bekerja/sekolah sebagian masih berada di Sekupang sendiri tepatnya di daerah industri Sagulung ,maupun di Sekupang dan di Tiban, yang lain tersebar di luar Kecamatan Sekupang, hal ini tidak jauh berbeda dengan di wilayah Nongsa perbedaannya tidak terlalu mencolok.Dan moda yang digunakan untuk tujuan perjalanan sehari-hari banyak menggunakan kendaraan Pribadi (Kendaraan motor dan Kendaraan mobil).pengguna kendaraan sepeda motor mencapai $33 \%$ dan pengguna mobil pribadi mencapai $35 \%$, Alasan menggunakan kendaraan pribadi bagi penduduk di Kecamatan Sekupang karena menggunakan kendaraan pribadi lebih hemat, nyaman.dengan prosentase $67 \%$ mereka menyatakan pendapatnya

Bahwa biaya yang dikeluarkan penduduk untuk transportasi antara Rp. $200.000-$ Rp.500.000 sebanyak $42 \%$, rata-rata bagi pengguna kendaraan pribadi, sedang penduduk dengan penghasilan lebih kecil biaya yang dikeluarkan untuk transportasi rata-rata $\leq \mathrm{Rp}$. 200.000 mereka lebih banyak menggunakan angkutan umum.

Untuk penduduk di Kecamatan Sei Beduk, Berdasarkan maksud perjalanan seharihari / utama bagi penduduk di Sei Beduk sebanyak $56 \%$ adalah untuk tujuan bekerja. Selain bekerja tujuan perjalanan yang lain seperti untuk sekolah sebanyak $30 \%$, dan selebihnya untuk tujuan belanja dan kegiatan sosial lainnya. Hal ini berbeda dengan yang terjadi di wilayah Sei Beduk dimana untuk tujuan perjalanan sehari-hari sebagian besar Penduduk Sei Beduk menempuh jarak perjalanan kurang dari atau $1-5 \mathrm{~km}$ justru sangat mencolok dibanding jarak yang lain.hal ini dipengaruhi keinginan responden dalam memilih tempat tinggal dekat dengan tempat kerja baik dengan cara membeli maupun sewa atau kontrak. (sebanyak $45 \%$ ) hingga 5 - $10 \mathrm{~km}$ ( sebanyak $28 \%$ ), dengan lama waktu perjalanan antara 20-30 menit hingga 30- 40 menit. Moda yang digunakan untuk melakukan perjalanan banyak 
menggunakan kendaraan roda dua sebanyak $24 \%$. dan menggunakan angkutan umum $42 \%$. Serta yang menggunakan kendaraan mobil sebanyak $34 \%$. Alasan mereka karena menggunakan kendaraan pribadi lebih hemat, nyaman dan bebas.dengan prosentase $67 \%$ mereka menyatakan pendapatnya, selain itu dengan menggunakan kendaraan pribadi bisa tepat waktu.

Biaya yang dikeluarkan untuk transportasi bagi penduduk Sei Beduk rata-rata sebesar $\leq$ Rp.200.000 per bulan. ( sebanyak $62 \%$ ) rata-rata mereka menggunakan moda angkutan umum, hingga Rp200.000 - 500.000 ( sebesar $31 \%$ ). Mereka cenderung menggunakan kendaraan pribadi. besarnya biaya transportasi hal ini juga sangat tergantung dari moda yang digunakan,serta jarak yang di tempuh.

\section{Karakteristik Pola Perjalanan Penduduk Pusat Kota ( Kecamatan Lubuk Baja)}

Maksud perjalanan sehari-hari / utama bagi penduduk di Lubuk Baja adalah sebagian besar adalah bekerja.yaitu sebanyak $63 \%$, Selain bekerja tujuan perjalanan yang lain seperti untuk sekolah sebanyak $25 \%$, serta untuk kegiatan sosial dan belanja masing-masing sebanyak $6 \%$. Dengan demikian bahwa aktifitas utama penduduk di Kecamatan Lubuk Baja adalah bekerja dan selebihnya untuk kegiatan yang lain.

Untuk tujuan perjalanan sehari-hari sebagian besar Penduduk Lubuk Baja menempuh jarak perjalanan 1 - $5 \mathrm{~km}$ (sebanyak $52 \%$ ) dengan lama perjalanan kurang dari atau sama dengan 10 menit, hingga $5-10 \mathrm{~km}$ ( sebanyak $27 \%$ ), dengan lama waktu perjalanan antara 20-30 menit hingga 30- 40 menit.besarnya jarak perjalanan yang di tempuh $1-5 \mathrm{~km}$ ini dilatar belakangi status pekerjaan responden lokasi pekerjaan relatif dekat tempat pekerjaan Moda yang digunakan untuk melakukan perjalanan banyak menggunakan kendaraan roda dua sebanyak $25 \%$.dan menggunakan angkutan umum $31 \%$. Serta yang menggunakan kendaraan mobil sebanyak $43 \%$.Alasan mereka karena menggunakan kendaraan pribadi lebih hemat,nyaman.dengan prosentase $66 \%$ mereka menyatakan pendapatnya,selain itu dengan menggunakan kendaraan pribadi bisa tepat waktu. Biaya yang dikeluarkan untuk transportasi bagi penduduk Lubuk Baja rata-rata sebesar $\leq$ Rp.200.000 per bulan. ( sebanyak $51 \%$ ), menggunakan angkutan umum/sepeda motor, hingga Rp 500.000 ( sebesar $45 \%$ ).mereka yang menggunakan kendaraan mobil pribadi, besarnya biaya transportasi hal ini juga sangat tergantung dari moda yang digunakan,serta jarak yang di tempuh. 


\section{Analisa Pola Perjalanan Transportasi Penduduk}

Untuk mengetahui pola perjalanan transportasi penduduk yang berada di daerah hinterland/pinggiran ( Kecamatan Nongsa, Kecamatan Sekupang, Kecamatan, Sei Beduk) Kota Batam maupun di pusat Kota Batam ( Lubuk Baja) dilakukan dengan analisa klasifikasi silang terhadap variabel yang mempunyai pengaruh terhadap pola perjalanan transportasi. variabel - variabel tersebut yaitu sebaran perjalanan, jumlah pendapatan, kepemilikan kendaraan, moda yang di gunakan, jarak perjalanan, waktu tempuhdan biaya transportasi.Berdasarkan hasil sebaran perjalanan penduduk di masing-masing-wilayah studi didapatkan hasil sebagai berikut :

Sebaran perjalanan penduduk di daerah pinggiran ( Kecamatan Nongsa, Kecamatan Sekupang, Kecamatan Sei Beduk ). Tujuan perjalanan penduduk di daerah pinggiran sebagian besar di wilayahnya masing-masing hal ini karena hampir meratanya kegiatankegiatan sektor industri di setiap wilayah kota Batam dan selebihnya menyebar ke berbagai wilayah di P Batam. serta sebagian kecil menyebar dikepulauan sekitar Pulau Batam.

Sebagian besar sebaran perjalanan penduduk di Kecamatan Nongsa atau sebanyak $23 \%$ melakukan perjalanan menuju ke industri Kabil, hal ini karena tempat tujuan aktifitas seharihari di daerah tersebut dan perjalanan yang menuju ke pusat kota ( Batam Centre) sebesar 12 $\%$ dan lainnya menyebar ke berbagai wilayah dalam P. Batam. Sedangkan Penduduk Sekupang, sebanyak $29 \%$ pergerakannya disekitar wilayah Sekupang, dan sebesar $19 \%$ menuju ke daerah industri Tanjung Uncang.dan lainnya menyebar ke berbagai wilayah di P. Batam dan sebagian kecil atau sebanyak $2 \%$ pergerakannya menuju ke kepulauan sekitar P. Batam. Untuk penduduk di Kecamatan Sei Beduk sebesar $29 \%$ pergerakan penduduknya menuju ke daerah industri Muka Kuning dan yang menuju ke pusat kota Batam Centre sebesar $14 \%$ hal ini karena tempat aktifitas bekerja sebagian besar terdapat di daerah tersebut.Demikian halnya untuk penduduk yang berada di pusat kota ( Lubuk Baja), sebaran perjalanan penduduknya sebagian besar menuju pusat kegiatan perkotaan (CBD) Nagoya sebesar $32 \%$. dan menuju ke industri Muka Kuning sebesar 17,0\% selebihnya menyebar keberbagai wilayah yang ada di dalam P. Batam.

Di wilayah Nongsa maupun di Sekupang sebagian besar mereka menempuh jarak perjalanan antara $1-5 \mathrm{~km}$ hingga $5-10 \mathrm{~km}$ ini di latar belakangi oleh status pekerjaan responden dimana lokasi pekerjaan relatif dekat dengan tempat tinggal yang akhirnya memperpendek jarak perjalanan yang harus di tempuh untuk mencapai tempat aktivitas.Hal ini berbeda yang terjadi di wilayah Sei Beduk dimana jarak yang di tempuh kurang dari $1 \mathrm{~km}$ hingga $5 \mathrm{~km}(45 \%$ ) cukup mencolok dibanding jarak tempuh perjalanan yang lain, 
tingginya prosentase jarak perjalanan kurang dari $1 \mathrm{~km}$ hingga $1-5 \mathrm{~km}$ juga di pengaruhi oleh keinginan responden sendiri memilih tempat tinggal yang dekat dengan tempat pekerjaan baik itu dilakukan dengan cara membeli rumah maupun kredit atau sewa/kontrak rumah.disamping itu adanya dukungan dari para investor yang membangun perumahan yang lokasinya tidak terlalu jauh dari tempat tinggal.

Dalam melakukan perjalanan pengaruh sensitif terhadap waktu, sehingga mereka lebih memilih kendaraan pribadi, dengan variasi jarak tempuh, ada sebagian yang menggunakan mobil dan sebagian yang lainnya menggunakan motor maupun angkutan umum.

Pemilihan penggunaan kendaraan oleh penduduk di daerah pinggiran hal ini lebih disebabkan pada status sosial ekonomi dan pengaruh perkembangan teknologi di samping itu didukung oleh tersediannya infrastruktur jalan dalam kondisi yang baik.

Moda yang digunakan untuk melakukan perjalanan, penduduk di daerah pinggiran seperti di daerah pinggiran Nongsa dan Sekupang cenderung lebih menggunakan kendaraan pribadi karena dinilai lebih aman,nyaman, namun ada hal yang berbeda di Sekupang sebanyak $2 \%$ mereka menggunakan moda perahu motor/pompong,bagi mereka yang bekerja di kepulauan sekitar Pulau Batam. Bahwa pengguna kendaraan pribadi di Nongsa seperti motor mencapai $36 \%$, sedang pengguna angkutan umum sebesar $32 \%$.sedangkan di Sekupang pengguna mobil sebesar $35 \%$. Hal ini berbeda dengan penduduk di Kecamatan Sei Beduk mereka lebih banyak menggunakan angkutan umum dalam melakukan perjalanan yaitu sebanyak $42 \%$, hal ini karena sarana dan prasarana yang memadai seperti jalan dan angkutan umumnya. dan yang menggunakan kendaraan pribadi mobil mencapai 34 $\%$.Dibanding pengguna angkutan umum di wilayah Nongsa dan Sekupang lebih sedikit hal ini karena jumlah angkutan umumnya kurang memadai.namun demikian sarana angkutan umum masih cukup diminati walaupun masih banyak kekurangannya.

\section{KESIMPULAN DAN SARAN}

\section{Kesimpulan}

Berdasarkan hasil tanggapan responden dan analisis data dari penduduk yang tinggal didaerah Hinterland/Pinggiran Kota Batam yaitu penduduk Kecamatan Nongsa, Kecamatan Sekupang, Kecamatan Sei Beduk dan penduduk yang tinggal di pusat kota yaitu penduduk Kecamatan Lubuk Baja maka dapat disimpulkan sebagai berikut : 
1. Penduduk memilih tempat tinggal di daerah pinggiran seperti di Kecamatan Nongsa, Kecamatan Sekupang, dan Kecamatan Sei Beduk, dikarenakan karena daerah tersebut merupakan daerah industri, yang didukung oleh pemukiman penduduk dan aksesibilitasnya mudah dijangkau. Sehingga mereka memilih daerah tersebut dengan alasan supaya dekat dengan tempat kerja, disamping itu harga rumah atau sewa masih relatif lebih murah.dari alasan yang mereka kemukakan penduduk di Kecamatan Nongsa sebanyak $46 \%$ menyatakan harga rumah atau sewa relatif lebih murah, Penduduk di Kecamatan Sekupang 31 \%, dan Penduduk di Kecamatan Sei Beduk sebanyak $32 \%$.

2. Sedangkan penduduk memilih tinggal di pusat kota ( Kecamatan Lubuk Baja) alasan mereka karena strategis untuk membuka usaha sebanyak $41 \%$ menyatakan pendapatnya, hal ini karena kedudukannya sangat strategis terhadap kota Batam yaitu sebagai pusat perdagangan,jasa,atau sebagai pusat CBD. Dan didukung industri di daerah sekitarnya.

3. Dari sebaran pergerakan penduduk di daerah pinggiran tersebut yaitu di Kecamatan Nongsa, Kecamatan Sekupang dan Kecamatan Sei Beduk sebagian besar pergerakannya masih diwilayahnya masing-masing dan sisanya menyebar ke berbagai wilayah di Pulau Batam.Untuk Penduduk Nongsa Sebanyak $23 \%$ pergerannya menuju daerah industri Kabil, dan menuju Pusat Kota Nagoya $12 \%$ hal ini tidak jauh berbeda dengan Di Kecamatan Sei Beduk sebanyak 29 \% tujuan perjalanan mereka ke industri Muka Kuning. Hal ini berbeda dengan Penduduk di Kecamatan Sekupang dengan sebaran pergerannya paling besar di Sekupang $29 \%$, disamping itu pergeran yang lain ke luar pulau Batam yaitu di kepulauan sekitar pulau Batam sebanyak $2 \%$. dengan moda yang mereka gunakan dalam perjalanan menggunakan perahu motor/pompong. Dengan waktu tempuh perjalanan 20 menit.

4. Untuk penduduk yang tinggal di pusat kota dalam hal ini di Kecamatan Lubuk Baja sebaran pergerannya sebagian besar menuju pusat Kota Nagoya $32 \%$ dan menuju ke pusat pemerintahan di Batam Centre $12 \%$. Dan lainnya menyebar ke wilayah lain yang ada di Pulau Batam.

5.Dalam melakukan perjalanan penduduk di pinggiran Kecamatan Nongsa dan Sekupang kendaraan pribadi masih menjadi pilihan utama untuk melakukan perjalanan sebanyak $36 \%$ penduduk Nongsa menggunakan Sepeda motor dan pengguna mobil $30 \%$. Sedangkan penduduk di Sekupang sebanyak $35 \%$, dalam melakukan perjalanan menggunakan mobil. Hal ini berbeda dengan penduduk yang ada di Kecamatan Sei Beduk sebanyak $42 \%$ mereka menggunakan angkutan umum dalam melakukan perjalanan hal ini karena aksesibilitasnya mudah dan sarana angkutannya cukup banyak 
dibanding di wilayah Nongsa dan sekupang, dan sebanyak $34 \%$ menggunakan kendaraan pribadi mobil.

6. Untuk penduduk di pusat kota ( Kecamatan Lubuk Baja) dalam melakukan perjalanan kendaraan pribadi ( mobil) menjadi pilihan utama mereka yaitu sebanyak $43 \%$ dengan alasan mereka merasa lebih nyaman,aman .

\section{Saran}

Saran atau rekomendasi yang dapat diberikan dari hasil penelitian ini adalah sebagai berikut :

1. Penggunaan moda pribadi bagi penduduk di wilayah Pingiran maupun di Pusat Kota perlu mendapat perhatian khusus dari pemerintah kota Batam sedini mungkin untuk perencanaan transportasi dimasa mendatang, Bagi penduduk dapat mempertimbangkan kembali penggunaan kendaraan pribadi dan untuk itu lebih meningkatkan dengan menggunakan angkutan umum. Hal ini menjadikan evaluasi pemerintah kota mapun dinas terkait untuk membuat kebijakan yang berhubungan dengan transportasi,untuk menyediakan angkutan umum yang nyaman, aman dan ketepatan waktu.misalnya dengan Shutle Bus dan transportasi massal yang diharapkan lebih memberikan kemudahan didalam penerapan konsep-konsep manajemen transportasi di massa mendatang agar bisa menekan penggunaan kendaraan pribadi.

2. Hasil penelitian ini dapat dijadikan bahan pendukung untuk pengembangan kawasan hunian terutama di daerah pinggiran/hinterland kota karena dalam penelitian ini di ketahui bahwa terdapat kecenderungan alasan penduduk memilih hunian dipinggiran karena harga rumah/sewa relatif lebih murah.dan karena ingin mendekatkan dengan tempat kerja dengan harapan bisa menghemat pengeluaran tiap bulan. Hal ini tantangan bagi para pengembang perumahan untuk menyediakan perumahan yang murah dan layak huni serta dengan harga yang terjangkau dari berbagai golongan ekonomi masyarakat terutama untuk ekonomi kecil, dan hal ini juga perlu dukungan dari Pemerintah.

3. Hasil penelitian ini juga dapat dijadikan bahan pendukung dalam bidang perencanaan transportasi,yang mana dalam penelitian ini diketahui penduduk cenderung menggunakan kendaraan pribadi dalam melakukan perjalanan karena mempunyai aksesibilitas yang tinggi serta pergerakan penduduk antar wilayah cukup besar baik yang menuju pusat kota maupun menuju ke pusat-pusat kegiatan industri, perdagangan dan lain- lain yang tersebar di wilayah Kota Batam. 


\section{DAFTAR PUSTAKA}

Alvinsyah \& Soehodho, S.,1997,Dasar-Dasar Sistem Transportasi,Laboratorium Transportasi Jurusan Teknik Sipil Fakultas Teknik Universitas Indonesia,Jakarta.

Brotowidjoyo,M.D.,1991,Metodologi Penelitian dan Penulisan Karangan Ilmiah,Penerbit Liberty, Yogyakarta

Hadi, S., 1995, Metodologi Research,Jilid 3 Penerbit Andi Offset. Yogyakarta.

Kamarwan.S.S., 1997., Sistem Transportasi,Penerbit Gunadarma, Jakarta.

Marzuki,1997, Metodologi Riset,Penerbit Fakultas Ekonomi UII, Yogyakarta.

Morlok,E.K., 1998.Pengantar Teknik dan Perencanaan Transportasi,Penerbit Erlangga Jakarta Pusat.

Nazir, M., 1983, Metodologi Penelitian, Penerbit Ghalia Indonesia, Jakarta.

Richardson, A.J., 1982., Transport Survey Methods,Departemen of Civil Engineering Monash University

Republik Indonesia, Otorita Pengembangan Daerah Industri Pulau Batam, Evaluasi Masterplan Barelang. LTFTUI.

Salter, R.J., 1974, Higway Traffic Analysis and Design. The Macmillan Press LTD,London and Basing Stoke.

Sugiarti, 2001, Teknik Sampling, Penerbit PT. Gramedia Pustaka Utama, Jakarta

Sugiyono,2002, Statistika untuk Penelitian, Penerbit Cv Alberta, Bandung.

Tamin, O.Z.,1997, Perencanaan dan Pemodelan Transportasi, Institut Teknologi Bandung.

Usman, H.\& Akbar, R.P.S., 1995, Pengantar Statistika, Penerbit PT.Bumi Aksara. Jakarta

Warpani,S., 1981, Perencanaan Transportasi, Institut Teknologi Bandung.

Warpani, S., 1988, Rekayasa Lalu Lintas, Penerbit Bhratara, Jakarta.

Warpani,S., 1990, Merencanakan Sistem Pengangkutan, Institut Teknologi Bandung.

Yunus,H.S.,2004., Struktur Tata Ruang Kota, Penerbit Pustaka Pelajar Offset, Yogyakarta 